\title{
DE
} DE GRUYTER OPEN

\section{SECTION OF CYBERNETICS IN MINING OF MINING COMMITTEE OF POLISH ACADEMY OF SCIENCES - PRO MEMORIA}

\author{
SEKCJA CYBERNETYKI W GÓRNICTWIE KOMITETU GÓRNICTWA PAN \\ - PRO MEMORIA
}

\begin{abstract}
Section of Cybernetics in Mining of Mining Committee of Polish Academy of Science (PAN) has been created by PAN Mining Committee in 1969. It was a section in Mining Committee of PAN, whose operation range included widely understood issues of automation, telecommunication and informatics in mining industry. The main operation method of the Section was to organize the periodic conferences dedicated to issues of control systems in mining. The first conference took place in 1971 in Katowice. Together with new (the current one) term of office of Mining Committee of PAN this Section ceased to exist. The paper presents (pro memoria) over 40 year long conference output of this Section that functioned within the scope of operation of Mining Committee of PAN up to $12^{\text {th }}$ January 2016.
\end{abstract}

Keywords: cybernetics, Section of Cybernetics in Mining, Committee of Mining of Polish Academy of Sciences

Sekcja Cybernetyki w Górnictwie Komitetu Górnictwa PAN została powołana przez Komitet Górnictwa PAN w 1969 r. W Komitecie Górnictwa PAN była to Sekcja, której zakres działania obejmował szeroko rozumiane zagadnienia automatyki, telekomunikacji i informatyki w górnictwie. Głównym sposobem działalności Sekcji była organizacja cyklicznych konferencji poświęconych zagadnieniom szeroko rozumianej automatyki w górnictwie. Pierwsza z konferencji odbyła się w 1971 r. w Katowicach. Wraz z nową kadencją funkcjonowania Komitetu Górnictwa PAN Sekcja ta przestała istnieć. Artykuł przedstawia (pro memoria) ponad 40 letni dorobek konferencyjny tej Sekcji funkcjonującej w ramach Komitetu Górnictwa PAN (do 12 styczna 2016 roku).

Słowa kluczowe: cybernetyka, Sekcja Cybernetyki w Górnictwie, Komitet Górnictwa Polskiej Akademii Nauk

* SILESIAN UNIVERSITY OF TECHNOLOGY, FACULTY OF MINING AND GEOLOGY, DEPARTMENT OF ELECTRICAL ENGINEERING AND CONTROL IN MINING, 2 AKADEMICKA STR., 44-100 GLIWICE, POLAND

\# Corresponding author: awojaczek@polsl.pl 


\section{Section of Cybernetics in Mining Committee of PAN (Polish Academy of Sciences)}

Polish Academy of Sciences (PAN) in present form had been created in 1952, after the first Congress of Polish Science that took place in Warsaw on the turn of June 1951. Scientists, members of PAN, create departments, committees as well as branch office of PAN. Tasks of given committee include, in particular, operation relating to significant problems of represented scientific domain as well as organizing debates and scientific conferences.

Mining Committee of PAN (KG PAN) is one of 21 committees of $4^{\text {th }}$ Department of PAN technical sciences. The basic tasks of Mining Committee of PAN are, among other: organizing, co-organizing the scientific conferences as well as dissemination of their results, undertaking activities that serve for development of mining sciences as well as similar scientific domains and development of opinions, expert opinions and scientific prognoses related to mining sciences as well as multi-domain developments.

The scientific structure of Mining Committee of PAN is composed of sections that deal with various domains of science related to mining. Issues related to widely understood automation, telecommunication as well as informatics in mining were included to operation of Section of Cybernetics in Mining. Section of Cybernetics in Mining was created by Mining Committee of Polish Academy of Sciences on June 23 ${ }^{\text {th }}, 1969$.

During the whole period of Section of Cybernetics in Mining the suggestions appeared to substitute the word "cybernetics" with other expression that describes the content-related scope of section operation, however, finally no decision was made to change the section name. Despite passage of 45 years as well as many suggestions to change the section name, expression "cybernetics", as a very generic term, corresponded with operation activities of this section during the whole time.

Norbert Wiener is considered as a creator of modern cybernetics. N. Wiener's work of title Cybernetics or Control and Communication in the Animal and the Machine, (Wiener, 1948) as well as W. Ashby's work An Introduction to Cybernetics (Ashby, 1957) may be considered as classic works of cybernetics beginning. The beginning of cybernetics in Poland is connected, among other, with M. Mazur's work (Mazur, 1976).

Norbert Wiener defined cybernetics as "the scientific study of control and communication in the animal and the machine."

According to encyclopaedia (Collective work, 1983), cybernetic, in wider meaning, is a domain of science that deals with issues connected with control (i.e. purposeful impact to processes that provides their desired course). According to Leksykon Naukowo-Techniczny (Collective work 2001), cybernetics is a science that deals with research of generic processes of communication and control occurring in machines, alive organisms and communities. In definitions cited above, there is a concept of control both in theoretical approach and in execution method.

Usage of word cybernetics in the name of one of sections of Mining Committee of PAN represents the subject matter of interest of Cybernetics Section in Mining. The said section dealt with issues of automation, telecommunication, informatics, telemetry, monitoring the engineering processes, monitoring the power system as well as organization and management taking into consideration the environment conditions of mines.

At present, these issues are still current due to limited employment, especially in workings of increased hazard. 
There were 9 sections during previous KG PAN term of office. There is 7 section in present term of office:

- Section of Mining Aerology (Prof. Ph.D. Eng., Stanisław Wasilewski),

- Section of Mining Economy and Organization (Prof. Ph.D. Eng., Marian Turek),

- Section of Rock Mechanics and Mining Construction (Prof. Ph.D. Eng., Piotr Czaja),

- Section of Mining Mechanization (Prof. Ph.D. Eng., Marian Dolipski),

- Section of Drilling and Borehole Mining (Prof. Ph.D. Eng., Stanislaw Rychlicki),

- Section of Mining Technology (Ph.D. Eng., Zbigniew Kasztelewicz, prof. AGH),

- Section of Ore (Ph.D Eng., Hubert Wirth, prof. PWr.).

The below mentioned Section was not reactivated: Section of Cybernetics in Mining as well as Section of Mineral Raw Materials Utilization.

The first chairman of Section of Cybernetics in Mining was Professor Ludger Mirosław SZKLARSKI from AGH (Mining and Metallurgy Academy) (1912-2003), who fulfilled this function by 27 years, until 1996 (Photograph No 1), then became a honourable member. Within 1996-1997 the function of chairman of the section was fulfilled by Professor Florian KRASUCKI (1928-1997) from Silesian University of Technology, Faculty of Mining and Geology, Department of Electrical Engineering and Control in Mining and since 1998 the work of Section of Cybernetics in Mining was managed by Professor Stanisław CIERPISZ from Silesian University of Technology, Faculty of Mining and Geology, Department of Electrical Engineering and Control in Mining.

\section{Features of organised conferences}

The basic task of every scientific section of Polish Academy of Science was, among other, co-organizing the scientific and technical conferences. In 2015 the section organised the last, jubilee $\left(40^{\text {th }}\right.$ one $)$ conference. Table 1 lists the collected by authors information about all conferences co-organised by Section of Cybernetics in Mining.

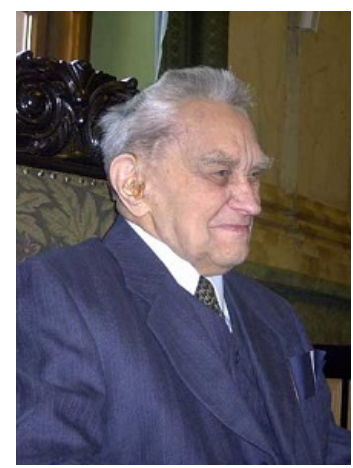

Prof. Ludger Szklarski 1969-1996

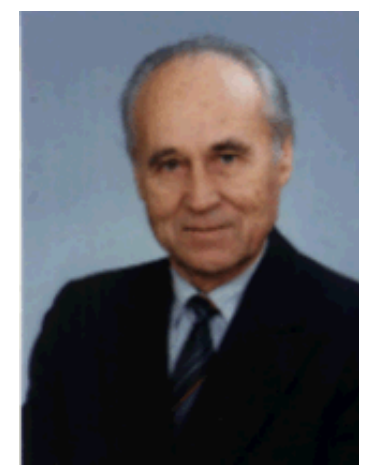

Prof. Florian Krasucki 1996-1997

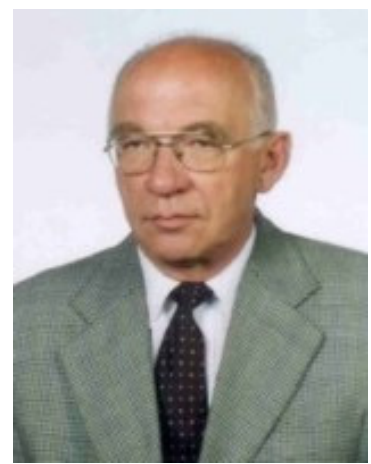

Prof. Stanisław Cierpisz 1997-2015

Photograph 1. Chairmens of Section of Cybernetics in Mining 
TABLE 1

List of conferences co-organized by Cybernetics Section in Mining of KG PAN together with leading subjects as well as institution who issued conference (printed) materials

\begin{tabular}{|c|c|c|c|c|}
\hline Year & Location & Leading subject & $\begin{array}{c}\text { Number } \\
\text { of papers }\end{array}$ & $\begin{array}{c}\text { Co-organizers / } \\
\text { publisher }\end{array}$ \\
\hline 1 & 2 & 3 & 4 & 5 \\
\hline 1971 & Katowice & Automation and Cybernetics in Mining & & $\begin{array}{c}\text { ZKMPW }^{1} / \\
\text { publisher ZKMPW }\end{array}$ \\
\hline 1973 & Zakopane & $\begin{array}{l}\text { Complex Automation and Engineering } \\
\text { Processes Modelling }\end{array}$ & 26 & $\begin{array}{c}\text { ZKMPW/ } \\
\text { publisher ZKMPW }\end{array}$ \\
\hline 1974 & Ustroń & $\begin{array}{l}\text { Optimum Control of Engineering } \\
\text { Processes in Mining }\end{array}$ & 22 & $\begin{array}{l}\mathrm{GIG}^{2}, \mathrm{RZPW}^{3} / \\
\text { publisher GIG }\end{array}$ \\
\hline 1975 & Nowa Ruda & Application of Computers in Mining & & \\
\hline 1976 & Jaszowiec & $\begin{array}{l}\text { Theory and Control Engineering in Mining } \\
\text { Work Safety Service }\end{array}$ & 22 & $\begin{array}{l}\mathrm{JMZPW}^{4} \text { i EMAG }^{5} / \\
\text { publisher EMAG }\end{array}$ \\
\hline 1977 & Zawoja & $\begin{array}{l}\text { Telecommunication and Telemetry in } \\
\text { Mining }\end{array}$ & 23 & $\begin{array}{l}\mathrm{KZPW}^{6} \text { EMAG / } \\
\text { publisher EMAG }\end{array}$ \\
\hline 1978 & Szczyrk & Automation of Coal Dressing Plants & 16 & $\begin{array}{c}\text { EMAG/ } \\
\text { publisher EMAG }\end{array}$ \\
\hline 1979 & $\begin{array}{l}\text { Szklarska } \\
\text { Poręba }\end{array}$ & $\begin{array}{l}\text { Management and Control Systems of } \\
\text { Mines }\end{array}$ & 26 & $\begin{array}{c}\text { EMAG/ } \\
\text { publisher EMAG }\end{array}$ \\
\hline 1980 & $\begin{array}{l}\text { Kazimierz } \\
\text { Dolny }\end{array}$ & Drives Control in Mining & 9 & $\begin{array}{c}\text { EMAG/ } \\
\text { publisher EMAG }\end{array}$ \\
\hline 1981 & Jaszowiec & $\begin{array}{l}\text { Automatization of Transportation in Coal } \\
\text { and Ore Underground Mining }\end{array}$ & 16 & $\begin{array}{c}\text { EMAG/ } \\
\text { publisher EMAG }\end{array}$ \\
\hline 1982 & Tresna & $\begin{array}{l}\text { Automatic Control and Early Detection of } \\
\text { Hazard in Mining }\end{array}$ & 20 & $\begin{array}{l}\text { EMAG, KWK } \\
\text { Wieczorek/ } \\
\text { publisher EMAG }\end{array}$ \\
\hline 1983 & Żelazno & $\begin{array}{l}\text { Theory and Technique of Transferring } \\
\text { Information in mining }\end{array}$ & 20 & $\begin{array}{c}\text { EMAG/ } \\
\text { publisher EMAG }\end{array}$ \\
\hline 1984 & $\begin{array}{c}\text { Rudy } \\
\text { Raciborskie }\end{array}$ & $\begin{array}{l}\text { Progress in Automation Development of } \\
\text { Coal Dressing Plants. }\end{array}$ & 21 & $\begin{array}{c}\text { EMAG/ } \\
\text { publisher EMAG }\end{array}$ \\
\hline 1985 & Zakopane & $\begin{array}{l}\text { Microprocessor Engineering in Control } \\
\text { and Inspection Systems of Engineering } \\
\text { Processes of Mines. }\end{array}$ & 17 & $\begin{array}{c}\text { EMAG/ } \\
\text { publisher EMAG }\end{array}$ \\
\hline 1986 & Bystra & $\begin{array}{l}\text { Automation Development in Mining of } \\
\text { Nineties. }\end{array}$ & 10 & $\begin{array}{c}\text { EMAG/ } \\
\text { publisher EMAG }\end{array}$ \\
\hline 1987 & $\begin{array}{c}\text { Rudy } \\
\text { Raciborskie }\end{array}$ & $\begin{array}{l}\text { Automation of Mining Complexes } \\
\text { and Transportation in Coal and Ore } \\
\text { Underground Mines }\end{array}$ & 20 & $\begin{array}{l}\text { EMAG/ } \\
\text { publisher EMAG }\end{array}$ \\
\hline
\end{tabular}

1 ZKMPW - Zakłady Konstrukcyjno-Mechanizacyjne Przemysłu Węglowego [Construction and Mechanization Works of Mining Industry].

2 GIG - Główny Instytut Górnictwa w Katowicach [Central Mining Institute in Katowice].

3 RZPW - Rybnickie Zjednoczenie Przemysłu Węglowego [The Rybnik Union of Coal Industry].

4 JMZPW - Jaworznicko-Mikołowskie Zjednoczenie Przemysłu Węglowego [The Jaworzno and Mikołów Union of Coal Industry].

5 EMAG - Ośrodek Badawczo Rozwojowy EMAG [Research-Development Centre EMAG] and later institutions created on the base of this entity.

6 KZPW - Katowickie Zjednoczenie Przemysłu Węglowego [The Katowice Union of Coal Industry]. 


\begin{tabular}{|c|c|c|c|c|}
\hline 1 & 2 & 3 & 4 & 5 \\
\hline 1988 & Wysowa & $\begin{array}{l}\text { Telecommunication and Telemetry in } \\
\text { Mining }\end{array}$ & 30 & $\begin{array}{c}\text { EMAG/ } \\
\text { publisher EMAG }\end{array}$ \\
\hline 1989 & Zarzecze & $\begin{array}{l}\text { Safety Parameters Inspection Systems in } \\
\text { Mining }\end{array}$ & 33 & $\begin{array}{c}\text { EMAG/ } \\
\text { publisher EMAG }\end{array}$ \\
\hline 1990 & $\begin{array}{c}\text { Ustroń } \\
\text { Zawodzie }\end{array}$ & $\begin{array}{l}\text { Monitoring and Automation in Mineral } \\
\text { Processing Plants. }\end{array}$ & 17 & $\begin{array}{c}\text { EMAG/ } \\
\text { publisher EMAG }\end{array}$ \\
\hline 1991 & $\begin{array}{c}\text { Rudy } \\
\text { Raciborskie }\end{array}$ & $\begin{array}{l}\text { Present Problems and Trends in } \\
\text { Development of Automation, Informatics } \\
\text { and Telecommunication }\end{array}$ & 7 & $\begin{array}{c}\mathrm{PCAMC}^{7} / \\
\left(\mathrm{MiAG}^{8}\right) 5 / 1991\end{array}$ \\
\hline 1992 & Jaworze & Transportation Automation in Mine & 18 & $\begin{array}{l}\text { EMAG, PCAMC / } \\
\text { MiAG nr 4-5/1992 }\end{array}$ \\
\hline 1993 & Zakopane & $\begin{array}{l}\text { Automation of Mining and Monitoring of } \\
\text { Safety Condition in Mine }\end{array}$ & 15 & $\begin{array}{l}\text { EMAG, PCAMC / } \\
\text { MiAG nr 5-6/1993 }\end{array}$ \\
\hline 1994 & Szczyrk & $\begin{array}{l}\text { Informatics and Telecommunication in } \\
\text { Mining }\end{array}$ & 27 & $\begin{array}{l}\text { EMAG, PCAMC/ } \\
\text { MiAG nr 5-6/1994 }\end{array}$ \\
\hline 1995 & Gliwice & $\begin{array}{l}\text { XII International Conference on } \\
\text { Automation in Mining and Quarries } \\
\text { ICAMC'95 }\end{array}$ & 175 & $\begin{array}{c}\mathrm{KEiAG}^{9}, \mathrm{PCAMC} / \\
\mathrm{KEiAG}^{2}\end{array}$ \\
\hline 1996 & $\begin{array}{l}\text { Ustroń } \\
\text { Jaszowiec }\end{array}$ & Automation in Mineral Processing. & 15 & $\begin{array}{c}\text { PCAMC } \\
\text { MiAG nr 12/1996 }\end{array}$ \\
\hline 1997 & Książ & $\begin{array}{l}\text { 25th Jubilee Symposium of Section of } \\
\text { Cybernetics in Mining and PCAMC. } \\
\text { Current Issues as well as Devices and } \\
\text { Mining Automation Systems }\end{array}$ & 44 & $\begin{array}{l}\text { PCAMC i KEiAG/ } \\
\text { MiAG nr 6-7/1997 }\end{array}$ \\
\hline 1998 & Krynica & $\begin{array}{l}\text { 26th Symposium of Section of Cybernetics } \\
\text { in Mining } \\
\text { Role of Automation in Solving the Current } \\
\text { Mining Problems }\end{array}$ & 17 & $\begin{array}{l}\text { PCAMC o KEiAG/ } \\
\text { Wiadomości } \\
\text { Górnicze nr 5/1998 }\end{array}$ \\
\hline 1999 & Zakopane & $\begin{array}{l}\text { PCAMC'99 } \\
\text { Automation, Telecommunication, } \\
\text { Informatics }\end{array}$ & 19 & $\begin{array}{l}\text { PCAMC i KEiAG/ } \\
\text { Wiadomości } \\
\text { Górnicze nr 5/1999 }\end{array}$ \\
\hline 2000 & Szczyrk & $\begin{array}{l}28^{\text {th }} \text { Conference on Automation and } \\
\text { Telecommunication in Mines and } \\
\text { Processing Plants - Coal and Minerals }\end{array}$ & 41 & $\begin{array}{c}\text { KEiAG i EMAG/ MiAG } \\
\text { nr 4-5/2000 }\end{array}$ \\
\hline 2001 & $\begin{array}{l}\text { Kudowa } \\
\text { Zdrój }\end{array}$ & $\begin{array}{l}29^{\text {th }} \text { Conference of Section of Cybernetics } \\
\text { in Mining and } 4^{\text {th }} \text { Conference on } \\
\text { telecommunication in mining KTG'2001 } \\
\text { as well as } 7^{\text {th }} \text { APPK Conference }{ }^{10} 2001\end{array}$ & $30^{11}$ & $\begin{array}{c}\text { KEiAG/ } \\
\text { publisher KEiAG }\end{array}$ \\
\hline
\end{tabular}

\footnotetext{
7 PCAMC - Polish Committee on Automation of Mines and Quarries.

8 MiAG - journal Mechanizacja i Automatyzacja Górnictwa. [Mechanization and Automation of Mining].

9 KEiAG - Katedra Elektryfikacji i Automatyzacji Górnictwa [Department of Electrical Engineering and Control in Mining].

${ }^{10}$ APPK - Automatyzacja Procesów Przeróbki Kopalin [Automation in Mineral Processing].

${ }^{11}$ The list did not take into consideration the papers published during APPK conferences; the materials from APPK conferences were always published as a separate book.
} 


\begin{tabular}{|c|c|c|c|c|}
\hline 1 & 2 & 3 & 4 & 5 \\
\hline 2002 & Szczyrk & $\begin{array}{l}\text { 30th Conference of Section of } \\
\text { Cybernetics in Mining, } 5^{\text {th }} \text { Conference } \\
\text { Telecommunication in Mining KTG'2002 } \\
\text { as well as } 8^{\text {th }} \text { Conference APPK'2002 }\end{array}$ & 23 & $\begin{array}{c}\text { KEiAG/ } \\
\text { publisher KEiAG }\end{array}$ \\
\hline 2003 & Szczyrk & $\begin{array}{l}31^{\text {st }} \text { Conference of Section of } \\
\text { Cybernetics in Mining, } 6^{\text {th }} \text { Conference on } \\
\text { Telecommunication in Mining ATI'2003 as } \\
\text { well as } 9^{\text {th }} \text { APPK Conference '2003 }\end{array}$ & 25 & $\begin{array}{c}\text { KEiAG/ } \\
\text { publisher KEiAG }\end{array}$ \\
\hline 2004 & Szczyrk; & $\begin{array}{l}32^{\text {nd }} \text { Conference of Section of Cybernetics } \\
\text { in Mining; Telecommunication and Safety } \\
\text { Systems in Mining ATI'2004 as well as } \\
10^{\text {th }} \text { Conference APPK'2004 }\end{array}$ & 28 & $\begin{array}{c}\text { KEiAG/ } \\
\text { publisher KEiAG }\end{array}$ \\
\hline 2005 & Szczyrk; & $\begin{array}{l}33^{\text {rd }} \text { International Conference of } \\
\text { Section of Cybernetics in Mining; } \\
\text { Telecommunication and Mining Safety } \\
\text { Systems. ATI'2005 as well as } 11^{\text {th }} \\
\text { Conference APPK'2005 }\end{array}$ & 32 & $\begin{array}{c}\text { KEiAG/ } \\
\text { publisher KEiAG }\end{array}$ \\
\hline 2006 & Szczyrk & $\begin{array}{l}34^{\text {th }} \text { International Conference of } \\
\text { Section of Cybernetics in Mining; } \\
\text { Telecommunication and Safety Systems } \\
\text { in Mining ATI'2006 as well as } 12^{\text {th }} \\
\text { Conference APPK'2006 }\end{array}$ & 31 & $\begin{array}{c}\text { KEiAG/ } \\
\text { publisher KEiAG }\end{array}$ \\
\hline 2007 & Jaworze & $\begin{array}{l}35^{\text {th }} \text { Conference of Section of Cybernetics } \\
\text { in Mining, Telecommunication and Safety } \\
\text { Systems in Mining ATI' } 2007 \text { as well as } \\
13^{\text {th }} \text { Conference APPK'2007 }\end{array}$ & 49 & $\begin{array}{l}\text { KEiAG, EMAG / } \\
\text { publisher EMAG }\end{array}$ \\
\hline 2008 & Szczyrk; & $\begin{array}{l}36^{\text {th }} \text { Conference of Section of Cybernetics } \\
\text { in Mining of KG PAN; Telecommunication } \\
\text { and Safety Systems in Mining ATI'2008 as } \\
\text { well as } 14^{\text {th }} \text { Conference APPK'2007 }\end{array}$ & 27 & $\begin{array}{c}\text { KEiAG/ } \\
\text { publisher KEiAG }\end{array}$ \\
\hline 2009 & Szczyrk; & $\begin{array}{l}37^{\text {th }} \text { Conference of Section of Cybernetics } \\
\text { in Mining of KG PAN; Telecommunication } \\
\text { and Safety Systems in Mining ATI'2009 as } \\
\text { well as } 15^{\text {th }} \text { Conference APPK' } 2009^{12}\end{array}$ & 29 & $\begin{array}{c}\text { KEiAG/ } \\
\text { publisher KEiAG }\end{array}$ \\
\hline 2010 & Szczyrk; & $\begin{array}{l}13^{\text {th }} \text { State Conference of Mining Electric } \\
\text { Engineering. KKEG. The Section fulfils } \\
\text { scientific patronage of the conference. }\end{array}$ & 23 & $\begin{array}{c}\text { KEiAG/ } \\
\text { publisher KEiAG }\end{array}$ \\
\hline 2011 & Szczyrk; & $\begin{array}{l}38^{\text {th }} \text { Conference of Section of Cybernetics } \\
\text { in Mining KG PAN; Telecommunication } \\
\text { and Mining Safety Systems ATI'2011. }\end{array}$ & 27 & $\begin{array}{c}\text { KEiAG/ } \\
\text { publisher KEiAG }\end{array}$ \\
\hline 2012 & Zakopane & $\begin{array}{l}14^{\text {th }} \text { State Conference of Mining Electric } \\
\text { Engineering KKEG.. The Section fulfils } \\
\text { scientific patronage of the conference. }\end{array}$ & 26 & $\begin{array}{c}\text { KEiAG/ } \\
\text { publisher KEiAG }\end{array}$ \\
\hline 2013 & Zakopane & $\begin{array}{l}39^{\text {th }} \text { Conference of Section of Cybernetics } \\
\text { in Mining KG PAN; Automatics, } \\
\text { Telecommunication, Informatics ATI'2013. }\end{array}$ & 29 & $\begin{array}{c}\text { KEiAG/ } \\
\text { publisher KEiAG }\end{array}$ \\
\hline
\end{tabular}

\footnotetext{
${ }^{12}$ Organisation of next APPK conferences was taken over by EMAG.
} 


\begin{tabular}{|c|c|l|c|c|}
\hline $\mathbf{1}$ & $\mathbf{2}$ & $\mathbf{3}$ & $\mathbf{4}$ & $\mathbf{5}$ \\
\hline 2014 & Szczyrk & $\begin{array}{l}15^{\text {th }} \text { State Conference of Mining Electric } \\
\text { Engineering KKEG.. The Section fulfils } \\
\text { scientific patronage of the conference. }\end{array}$ & 26 & $\begin{array}{c}\text { KEiAG/ } \\
\text { publisher KEiAG }\end{array}$ \\
\hline 2015 & Szczyrk & $\begin{array}{l}\mathbf{4 0}^{\text {th }} \text { Jubilee Conference of Section } \\
\text { of Cybernetics in Mining KG PAN; } \\
\text { Automatics, Telecommunication, } \\
\text { Informatics ATI'2015. }\end{array}$ & 24 & $\begin{array}{c}\text { KEiAG/ } \\
\text { publisher KEiAG }\end{array}$ \\
\hline
\end{tabular}

At the beginning years every conference was dedicated to a specific subject, for instance, to automatization of coal face machines, communication system, transportation automatization, safety systems, etc. Later, during conferences of Section of generic name Automatics, Telecommunication, Informatics (ATI) the above mentioned issues were touched in separate subject sections of this conference.

During the first years of Section operation the decision was made about annual organisation of scientific and technical conferences as meeting of scientists, manufactures and practicians interested in widely understood cybernetics in mining. Organisation of conferences as well as publication of conference materials was at the beginning undertaken by ZKMPW [Construction and Mechanisation Works of Mining Industry] in Katowice as well as GIG [Central Mining Institute] in Katowice.

After division of ZKMPW into two centres in 1975: KOMAG Gliwice as well as OBR SMEAG Katowice (Research and Development Centre of Mechanisation, Electrical Engineering and Mining Automation) and decision, that issues connected with electrical engineering, automation, telecommunication and informatics is overtaken by Centrum Naukowo-Produkcyjne (Manufacture and Scientific Centre) EMAG in Katowice (CNP EMAG) and its Research and Development Center (OBR EMAG) these conferences were organized first of all by OBR EMAG, and from time to time with some mines or with unions of coal industry. The history outline of EMAG and operation of EMAG Institute is presented widely in monograph (Trenczek, 2015). The present name of this entity is Instytut Technik Innowacyjnych (Institute of Innovative Technologies) ITI EMAG. Research and Development Center EMAG and later institutions created on the basis of this entity, shall be named in abbreviation as EMAG.

The significant contribution into organisation of the first conferences had professors from AGH: Profesor Ludger Szklarski and Profesor Roman Wojnicki as well as employees of OBR EMAG in Katowice: Ph. D. Eng. Bolesław Firganek, secretary of many years of Cybernetics Section and M.Sc. eng. Kalikst Marcinkowski.

In 1991, the co-organisers of Section of Cybernetics conference was PCAMC (Polish Committee on Automation of Mines and Quarries), and conference proceedings were published as a special issue of journal of Mechanizacja i Automatyzacja Górnictwa (Mechanization and Automation of Mining) or as a special issue of journal of Wiadomości Górnicze (Mining News).

PCAMC is Polish unit of ICAMC (International Committee on Automation of Mines and Quarries). Committee ICAMC was set up in 1967 and worked as the independent international association till 1987 organizing 8 international conferences in different East European Countries. In 1987 the Committee was affiliated to the International Organizing Committee of World Mining Congress as the associated organization. Up to 2000 ICAMC was continuing organization of the separate conferences, till the changes in the World market showed the usefulness of incorporation these conferences to the World Mining Congress. 
In 1995, for the second time in Poland, at Technical University of Silesia the international conference was organized, i.e. XII International Conference on Automation in Mining and Quarries ICAMC'95 together with ICAMC committee and Section of Cybernetics in Mining.

In 1995, Department of Electrical Engineering and Control in Mining (KEiAG) of Technical University of Silesia was included to conference organisation. Since 2000 the conferences were organised together with KEiAG as well as with EMAG.

Within 2001 - 2009 Department of Electrical Engineering and Control in Mining (EiAG) of Silesian University of Technology together with Section of Cybernetics in Mining, organised conferences named Automation of Mineral Raw Materials Dressing Plants (APPK). Proceedings of these conferences were also published by Department of Electrical Engineering and Control in Mining of Silesian University of Technology as a separate publication. Professor Stanisław Cierpisz had a large contribution into APPK conferences organisation.

Since 2003, as opposed to other conferences as were already organized first of all by manufacturers of various machines and devices for mining, the conferences of Cybernetics Section related to automation, telecommunication and informatics assumed the uniform name ATI (abbreviation for Automatics, Telecommunication, Informatics). Since 2010, Section of Cybernetics in Mining organizes also The State Conferences of Mining Electric Engineering.

In Fig. 1-3 cover pages examples are presented of conference preceedings of Section of Cybernetics in Mining of various years:

- proceedings published by ZKMPW (Fig. 1),

- proceednigs of ATI Conference (Fig. 2) published as books by KEiAG (with ISBN No ${ }^{13}$ ),

- proceednigs of APPK Conference (Fig. 3) published as books by KEiAG (with ISBN No).

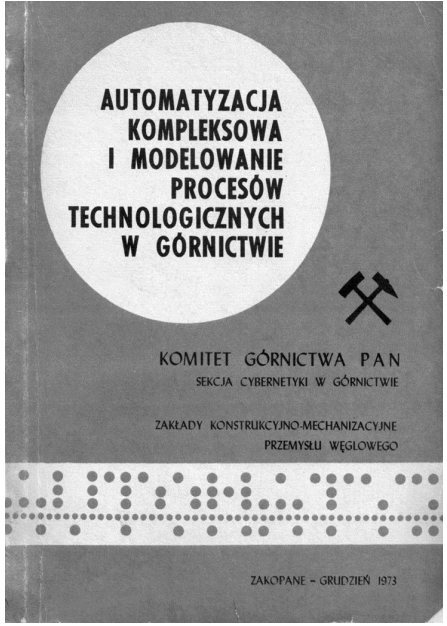

Fig. 1. Cover page of proceedings of 2 nd conference of Section of Cybernetics in Mining issued by ZKMPW in Katowice

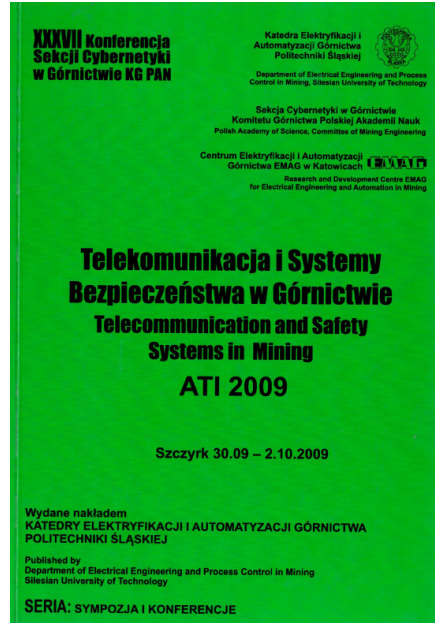

Fig. 2. Cover page of ATI conference preceedings published by KEiAG since 2002

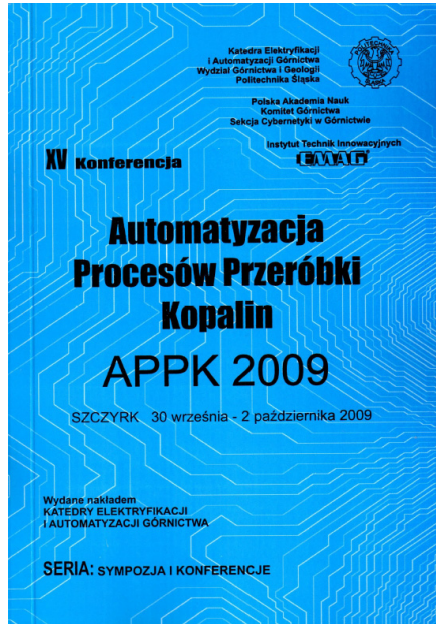

Fig. 3. Cover page of APPK conference preceedings published by KEiAG since 2002

\footnotetext{
${ }^{13}$ ISBN - International Standard Book Number - unrepeated 13 digit book identifier.
} 


\section{Summary}

The conferences organized by Section of Cybernetics in Mining constituted through 45 years the most important forum that presented the issues of cybernetics, automation, telecommunication and informatics in mining developed in form of theoretic papers, presentation of ready solutions for mining, experiences from operation of devices and systems. Within the scope of conferences, technical expositions of automation and telecommunication devices provided for mining as well as presentation of companies were organized. Contacts between scientists, constructors, users, manufacturer of devices and service companies constituted the essential component of every conference.

Within these years, a lot of people had contributed to success of these conferences and efficient functioning of Section of Cybernetics in Mining of Mining Committee. Authors within over 20 years organized the Cybernetics Section conferences. They managed to collect all conference proceedings. This is almost 1200 conference papers. They are available in the library of Department of Electrical Engineering and Control in Mining. Conference proceedings published with ISBN number are also available in National Library. Some proceednigs (published after 2000) are also available in German National Library of Science and Technology (TIB) and University Library Hannover.

\section{References}

Ashby W.R., 1957. Introduction to Cybernetics. Chapman \& Hall LTD. London.

Conference materials of Cybernetics Section in Mining of PAN of separate years. Authors' private collection.

Collective work, 1983. Encyklopedia PWN. Warsaw.

Collective work, 2001. Leksykon naukowo-techniczny. PWN. Warsaw.

Mazur M., 1976. Cybernetics and character. PWN Warszawa.

Trenczek S. (Ed.), 2015. Instytut Technik Innowacyjnych EMAG (Institute for Innovation Engineering): 40 years of innovation for economy. Monography of EMAG. Katowice.

Wiener N., 1948. Cybernetics, or Control and Communication in the Animal and the Machine. Cambridge: MIT Press. 